\title{
触 New Disease Reports \\ First outbreak of Pepper vein yellows virus infecting sweet pepper in Italy
}

\author{
S. Panno ${ }^{1}$, C. Biondo ${ }^{1}$, V. Piazza ${ }^{1}$, S. Graci ${ }^{1,2}$, A. Alfaro ${ }^{2}$, M.I. Font ${ }^{2}$, S. Marchione ${ }^{3}$, M. Davino ${ }^{4}$, P. Bella ${ }^{1}$ and S. Davino ${ }^{1,5 *}$ \\ ${ }^{1}$ Department of Agriculture and Forest Science, University of Palermo, Viale delle Scienze Ed. 5, 90128 Palermo, Italy; ${ }^{2}$ \\ Grupo de Virología, Instituto Agroforestal Mediterráneo, Universitat Politènica de València, Camino de Vera $s / n, 46022$ \\ Valencia, Spain; ${ }^{3}$ Osservatorio per le Malattie delle Piante, Via Uditore 15, 90145 Palermo, Italy; ${ }^{4}$ Department Di3A - \\ University of Catania, Via S. Sofia 100, 95100 Catania, Italy; ${ }^{5}$ Institute for Sustainable Plant Protection - National Research \\ Council (IPSP-CNR), Strada delle Cacce 73, 10135 Torino, Italy
}

*E-mail: salvatore.davino@unipa.it

Received: 31 May 2016. Published: 21 Jul 2016. Keywords: emerging pathogen, PeVYV, Poleroviruses

Sweet pepper (Capsicum annum) is an economically important crop worldwide, including Sicily where about 4,000 hectares are grown each year. In October 2015, severe symptoms not previously reported by growers in the horticultural area of the province of Trapani (Sicily, Italy) were observed on sweet pepper plants in eight different greenhouses. Symptoms included upward leaf curling, internodal shortening and interveinal yellowing. Symptoms were more evident in the upper part of the plants. These symptoms were reminiscent of those caused by poleroviruses. In the greenhouse, symptoms were evident in about $35 \%$ of the plants. Three samples per greenhouse ( 24 in total) were collected for analysis.

Total RNA was extracted from young leaves of 12 symptomatic plants using an RNA extraction kit (Qiagen, Germany) according to the manufacturer's instructions. Reverse transcription polymerase chain reaction (RT-PCR) was performed with primers Pol-G-F and Pol-G-R designed for universal detection of poleroviruses by amplifying parts of the RNA-dependent RNA polymerase (RdRp) and coat protein (CP) genes (Knierim et al., 2010). All 24 samples were positive following RT-PCR whereas healthy controls gave negative results. The amplicons generated from three samples were purified using the UltraClean ${ }^{\circledR}$ PCR Clean-Up kit (Mo-Bio, USA) and the nucleotide sequences were determined in both directions using an ABI 3130XL Genetic Analyzer (Life Technologies, USA). The sequences obtained from the three samples were $99 \%$ identical and the sequence of one isolate was deposited in GenBank (Accession No. KX343894). Subsequent BLAST analysis revealed that the sequence of the new isolate was $>98 \%$ identical to the sequence of a Spanish isolate of Pepper vein yellows virus (PeVYV) isolate from Almeria (KC839992; Villanueva et al., 2013).

Pepper vein yellows virus is a member of the genus Polerovirus, family Luteoviridae (Murakami et al., 2011). Poleroviruses are transmitted by aphids in a persistent (circulative) and non-propagative manner (Raccah et al., 2009; Dombrovsky et al., 2010). To our knowledge, this is the first report of PeVYV in Italy. PeVYV has the potential to cause significant to pepper crops; however, anti-aphid treatments were done to prevent the spread of disease to other areas.

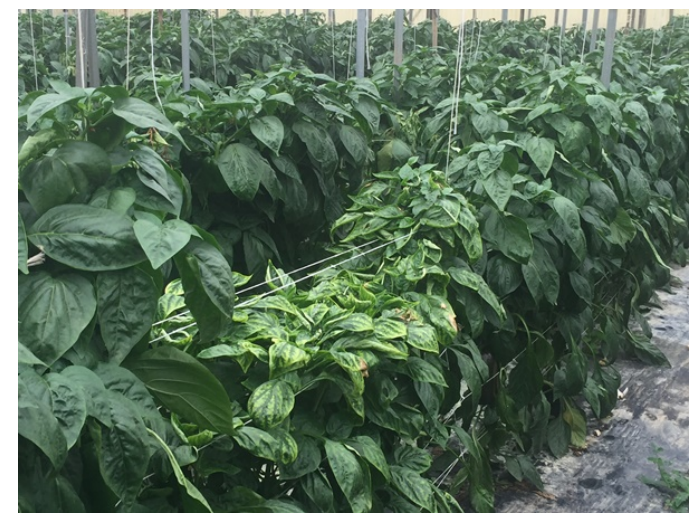

Figure 1

Sicily is one of the most important horticultural regions in the European Union and this makes the island an epicentre for the movement of plant material, increasing the risk of introducing new diseases. The economy could be adversely affected by these new introductions and Sicilian horticulture would be particularly at risk.

\section{Acknowledgements}

The authors would like to thank Dr. Vito Adragna of the Servizi Fitosanitari di Trapani, U.O. 173.

\section{References}

Dombrovsky A, Glanz E, Pearlsman M, Lachman O, Antignus Y, 2010. Characterization of Pepper yellow leaf curl virus, a tentative new Polerovirus species causing a yellowing disease of pepper. Phytoparasitica 38, 477-486. http://dx.doi.org/10.1007/s12600-010-0120-x

Knierim D, Deng TC, Tsai WS, Green SK, Kenyon L, 2010. Molecular identification of three distinct Polerovirus species and a recombinant Cucurbit aphid-borne yellows virus strain infecting cucurbit crops in Taiwan. Plant Pathology 59, 991-1002. http://dx.doi.org/10.1111/j.1365-3059.2010.02327.x

Murukami R, Nakashima N, Hinomoto N, Kawano S, Toyosato T, 2011 The genome sequence of pepper vein yellows virus (family Luteoviridae, genus Polerovirus). Archives of Virology 156, 921-923. http://dx.doi.org/10.1007/s00705-011-0956-5

Raccah B, Fereres A (2009) Insect transmission of plant viruses. UK Encyclopedia of Life Science, London, UK, John Wiley \& Sons Ltd. http://dx.doi.org/http://dx.doi.org/10.1002/9780470015902.a0000760.pub2

Villanueva F, Castillo P, Font MI, Alfaro-Fernández A, Moriones E, NavasCastillo J, 2013. First report of Pepper vein yellows virus infecting sweet pepper in Spain. Plant Disease 97, 1261.

http://dx.doi.org/10.1094/PDIS-04-13-0369-PDN

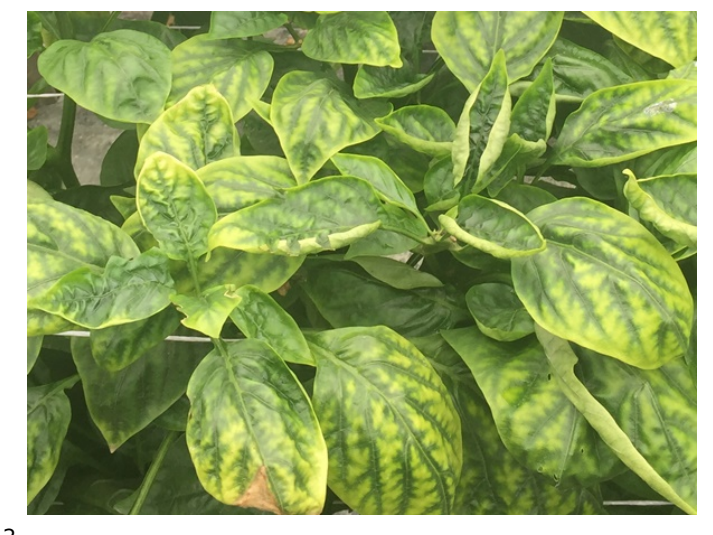

To cite this report: Panno S, Biondo C, Piazza V, Graci S, Alfaro A, Font MI, Marchione S, Davino M, Bella P, Davino S, 2016. First outbreak of Pepper vein yellows virus infecting sweet pepper in Italy. New Disease Reports 34, 3. http://dx.doi.org/10.5197/j.2044-0588.2016.034.003 (c) 2016 The Authors This report was published on-line at www.ndrs.org.uk where high quality versions of the figures can be found. 